\title{
Maastricht University Graduate Surveys 2018
}

Citation for published version (APA):

van Eldert, P., \& Künn, A. (2018). Maastricht University Graduate Surveys 2018. ROA. ROA Fact Sheets No. 009 https://doi.org/10.26481/umarof.2018009

Document status and date:

Published: 01/01/2018

DOI:

10.26481/umarof.2018009

Document Version:

Publisher's PDF, also known as Version of record

\section{Please check the document version of this publication:}

- A submitted manuscript is the version of the article upon submission and before peer-review. There can be important differences between the submitted version and the official published version of record.

People interested in the research are advised to contact the author for the final version of the publication, or visit the DOI to the publisher's website.

- The final author version and the galley proof are versions of the publication after peer review.

- The final published version features the final layout of the paper including the volume, issue and page numbers.

Link to publication

\footnotetext{
General rights rights.

- You may freely distribute the URL identifying the publication in the public portal. please follow below link for the End User Agreement:

www.umlib.nl/taverne-license

Take down policy

If you believe that this document breaches copyright please contact us at:

repository@maastrichtuniversity.nl

providing details and we will investigate your claim.
}

Copyright and moral rights for the publications made accessible in the public portal are retained by the authors and/or other copyright owners and it is a condition of accessing publications that users recognise and abide by the legal requirements associated with these

- Users may download and print one copy of any publication from the public portal for the purpose of private study or research.

- You may not further distribute the material or use it for any profit-making activity or commercial gain

If the publication is distributed under the terms of Article $25 \mathrm{fa}$ of the Dutch Copyright Act, indicated by the "Taverne" license above, 


\section{Maastricht University $\$$ ROA}

\section{Maastricht University Graduate Surveys 2018}

Peter van Eldert

Annemarie Künn

\section{ROA Fact Sheet}

ROA-F-2018/9

Researchcentrum voor Onderwijs en Arbeidsmarkt | ROA Research Centre For Education and the Labour Market / ROA 


\section{Maastricht University Graduate Surveys 2018}

To what extent facilitates Maastricht University her students in their preparation for entering the labour market? Are Maastricht University alumni employable in both the short and the long run? This factsheet shows to what extent alumni from all faculties are and will remain employable, and is based on alumni research among three cohorts in 2017. The first cohort graduated in academic year 2015-2016, the second cohort graduated in academic year 2011-2012, and the third cohort graduated in academic year 2006-2007. ${ }^{1}$

\section{Position in the labour market}

Of all Maastricht University alumni who graduated 1.5 years ago, $91 \%$ is reported to be part of the labour force, nearly half of the $9 \%$ reported out of the labour force is still studying. ${ }^{2}$ Five and ten years after graduation more alumni are part of the labour force, $95 \%$ and $96 \%$ respectively.

Table 1 shows the unemployment rates for UM alumni by cohort and faculty. Alumni are unemployed if they are, at the time of the survey, not working but searching for work. Of the alumni who graduated 1.5 years ago, $7 \%$ turn out to be unemployed, whereas the cohorts five and ten years after graduation have an unemployment rate of $2 \%$ and $3 \%$ respectively. These percentages are comparable to those of last year. ${ }^{3}$ The unemployment rate 1.5 years after graduation is with $7 \%$ a little higher than the average among alumni from all Dutch universities (which equals 5\%).

The unemployment rates vary substantially across faculties, as shown by Table $1 .{ }^{4}$ The highest unemployment rate is found among the alumni from the Faculty of Arts and Social Sciences 1.5 years after

1 The response rates for these graduation cohorts are: $16.5 \%$ for $2015-2016,26 \%$ for $2011-2012,21 \%$ for $2006-2007$. Because of the low initial response rate, alumni from the cohorts 2015-2016 and 2011-2012 were additionally called to remind them of responding to the questionnaire.

2 Based on the ILO definition of (un)employment.

3 See ROA-F-2017/1.

4 There is a difference in the unemployment rates within the Faculty of Health, Medicine and Life Sciences. The unemployment rate 1.5 years after graduation is $7 \%$ for alumni from Health and Life Sciences and $4 \%$ for alumni from Medicine. Five and ten years after graduation the unemployment rate among Health and Life Sciences alumni is $2 \%$ and $1 \%$ respectively. Among Medicine alumni this percentage is zero for both cohorts. graduation. This percentage is much higher than among alumni from other faculties graduated in the same year, and it is also much higher than the percentage of unemployed alumni from the same faculty, who graduated approximately five and ten years ago. ${ }^{5}$ Also among alumni from Health, Medicine and Life Sciences and Psychology and Neuroscience the unemployment rate among alumni from the most recent cohort is larger than among alumni from the other two cohorts, though the differences are not so large as for Arts and Social Sciences. The lowest unemployment rates are found among alumni from the School of Business and Economics. In the most recent cohort the unemployment rate is zero and for the other two cohorts $1 \%$.

TABLE 1.

Percentage of students who are unemployed

\begin{tabular}{|l|c|c|c|} 
& \multicolumn{3}{|c|}{ \% unemployed } \\
\hline Humanities and Sciences & $2015-2016$ & $2011-2012$ & $2006-2007$ \\
\hline Business and Economics & 5 & 7 & $x$ \\
\hline Health, Medicine and Life & 0 & 1 & 1 \\
\hline Sciences & 6 & 1 & 1 \\
\hline Arts and Social Sciences & 23 & 6 & 5 \\
\hline Psychology and Neuroscience & 7 & 4 & 4 \\
\hline Law & 8 & 2 & 7 \\
\hline Maastricht University & 7 & 2 & 3 \\
\hline
\end{tabular}

$x=$ too few cases

\section{Trends in unemployment}

Figure 1 shows the trend in the unemployment rate among the UM alumni who graduated 1.5 years before the survey for the period 2005 to $2017 .{ }^{6}$ Related to the economic crisis, we observe an increase in the unemployment rate between 2007 and 2013. In the following two years, the UM wide unemployment rate

5 Last year, the percentage unemployed among alumni from Arts and Social Sciences 1.5 years after graduation was $6 \%$. The high unemployment rate of this year's most recent cohort seems to be an outlier.

6 The trend in unemployment rates five and ten years after graduation are not shown as there is not much variation over time. 


\section{Factsheet}

ROA-F-2018/9

decreased again. Since 2015, the unemployment rate is stable around $7 \%{ }^{7}$

\section{FIGURE 1.}

Trends in unemployment rates 1.5 years after graduation

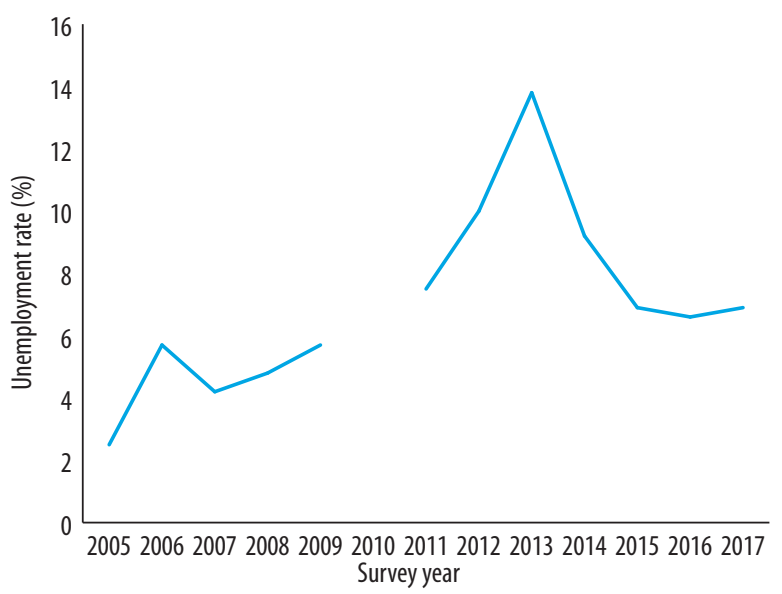

\section{Vertical and horizontal match}

It is not only important to have a job; the requirements of the job should also match the alumni's education. A well-matched job not only shows that the knowledge and skills acquired during their study time at the UM are used in the labour market, but such a job often also implies higher job satisfaction, more career opportunities and less sickness absence. ${ }^{8}$ Table 2 a shows the extent to which UM alumni experience a vertical match. For each graduation cohort, the percentage of alumni is shown that have job at university master level. The table shows that the majority of UM graduates is able to find a job at the attained educational level. $68 \%$ of the alumni who graduated 1.5 years ago, has a job at university master level. The probability of a vertically matched job seems to increase with the years since graduation. Among the UM alumni who graduated approximately five and ten years ago, respectively $70 \%$ and $77 \%$ has a job at university master level. Across faculties there is variation in the percentage alumni with

7 The extremely high unemployment rate among alumni from Arts and Social Sciences prevent the overall UM unemployment rate to decline further in 2017.

8 See for example: Lee, Y., \& Sabharwal, M. (2016). Education-Job match, salary, and job satisfaction across the public, non-Profit, and for-Profit sectors: Survey of recent college graduates. Public Management Review, 18(1), pp 40 -64 . a vertical match. The Faculty of Arts and Social Sciences appears to have the lowest percentage of graduates that are vertically matched 1.5 and five years after graduation ( $56 \%$ and $45 \%$ respectively). These relatively low percentages are in sharp contrast to the relatively high percentage of alumni who graduated ten years ago at the same faculty (81\%). Among alumni from Humanities and Sciences who graduated in 2011-2012, 91\% has a job at university master level. Alumni from Health, Medicine and Life Sciences also have a relatively high vertical match percentage five years after graduation (86\%). 9 Alumni from Psychology and Neuroscience have a somewhat below average probability of a vertically well-matched job 1.5 and five years after graduation (61\% and $64 \%$ respectively), but a high probability of a job at university master level ten years after graduation (85\%).

\section{TABLE $2 a$.}

Percentage of graduates who have a vertical match

\begin{tabular}{|l|c|c|c|}
\hline & \multicolumn{4}{|c|}{ \% working at university level or higher } \\
\hline & $2015-2016$ & $2011-2012$ & $2006-2007$ \\
\hline Humanities and Sciences & 60 & 91 & $\mathrm{X}$ \\
\hline Business and Economics & 65 & 65 & 73 \\
\hline Health, Medicine and Life & 77 & 86 & 77 \\
\hline Sciences & & & \\
\hline Arts and Social Sciences & 56 & 45 & 81 \\
\hline Psychology and Neuroscience & 61 & 64 & 85 \\
\hline Law & 64 & 68 & 77 \\
\hline Maastricht University & 68 & 70 & 77 \\
\hline
\end{tabular}

$\mathrm{x}=$ too few cases

Table $2 b$ shows the percentage of Maastricht University graduates that is currently working in their own field of study or a related field of study, the so-called horizontal job match. Similar to Table $2 \mathrm{a}$, the majority of Maastricht University graduates is able to find a job that is in their own - or a related - field of study. Of the cohort 1.5 year after graduation, $74 \%$ is horizontally well-matched, whereas for the cohorts five and ten years after graduation $79 \%$ and $78 \%$ respectively is horizontally well-matched. Again, differences across faculties exist. Alumni from Humanities and Sciences as well as from Arts and Social Sciences report on average

9 There are differences among Faculty of Health, Medicine, and Life Sciences alumni. Across cohorts, the percentages Health and Life Sciences alumni with a vertical match are $62 \%, 78 \%$ and $72 \%$ respectively. In contrast, all Medicine alumni are vertically matched 1.5 and five years after graduation. Ten years after graduation this percentage is $97 \%$. 


\section{Maastricht University Graduate Surveys 2018}

a relatively low percentage of horizontally matched jobs. However, this might be due to the general character of most master programmes belonging to these faculties. ${ }^{10}$ The percentage of alumni who experience a horizontal match is, among all cohorts, relatively high for Health, Medicine and Life Sciences." Psychology and Neuroscience alumni ten years after graduation, as well as Law alumni five years after graduation also have above average probability of a job in their own (or a related) field of study.

TABLE 2b.

Percentage of graduates who have a horizontal match

\begin{tabular}{|l|c|c|c|}
\hline & \multicolumn{4}{|c|}{ \% working in own or related field of study } \\
& $2015-2016$ & $2011-2012$ & $2006-2007$ \\
\hline Humanities and Sciences & 55 & 70 & $\mathrm{X}$ \\
\hline Business and Economics & 71 & 81 & 81 \\
\hline Health, Medicine and Life & 85 & 89 & 83 \\
\hline Sciences & & & \\
\hline Arts and Social Sciences & 56 & 48 & 49 \\
\hline Psychology and Neuroscience & 74 & 68 & 88 \\
\hline Law & 67 & 86 & 71 \\
\hline Maastricht University & 74 & 79 & 78 \\
\hline
\end{tabular}

$x=$ too few cases

\section{Income and working hours}

Table 3 shows the median monthly gross income and weekly working hours across the three cohorts and six faculties. On average, 1.5 years after graduation, Maastricht University alumni have a median monthly income of $€ 2,600$. The median income increases to $€ 3,800$ and $€ 4,500$, five and ten years after graduation respectively. While School of Business and Economics alumni appear to consistently have a relatively high median income across the cohorts, it should be noted that these graduates also report a relatively high median weekly working hours. Except for alumni from the School of Business and Economics, most UM alumni work between 36 and 40 hours per week, which boils down to a full-time job.

10 The vast majority of the FHS and FASoS alumni who are not horizontally matched indicate that their current job did not require a specific field of study.

11 These percentages are mainly driven by Medicine alumni, for all cohorts around $95 \%$ of the Medicine alumni is horizontally matched.
For most faculties, the median income ten years after graduation is about doubled compared to 1.5 years after graduation. This does not hold for the alumni from Health, Medicine and Life Sciences, who start with a relatively high median income 1.5 years after graduation. ${ }^{12}$ Ten years after graduation, they have a below average median income, leaving ahead alumni from the School of Business and Economics as well as alumni from Law. Alumni from Psychology and Neuroscience have the lowest median income five and ten years after graduation. This might be due to a lower number of working hours, which in turn can be related to the relatively high percentage of alumni that is selfemployed next to their job for an employer. ${ }^{13}$

TABLE 3.

Median monthly income and weekly working hours

\begin{tabular}{|c|c|c|c|c|c|c|}
\hline & \multicolumn{3}{|c|}{$\begin{array}{l}\text { gross income per month } \\
\text { (median) }\end{array}$} & \multicolumn{3}{|c|}{$\begin{array}{l}\text { regular working hours } \\
\text { per week (median) }\end{array}$} \\
\hline & $\begin{array}{c}2015 \\
- \\
2016\end{array}$ & $\begin{array}{c}2011 \\
- \\
2012\end{array}$ & $\begin{array}{c}2006 \\
- \\
2007\end{array}$ & $\begin{array}{c}2015 \\
- \\
2016\end{array}$ & $\begin{array}{c}2011 \\
- \\
2012\end{array}$ & $\begin{array}{c}2006 \\
- \\
2007\end{array}$ \\
\hline Humanities and Sciences & $x$ & 3,775 & $x$ & 40 & 40 & $x$ \\
\hline Business and Economics & 2,870 & 4,800 & 5,500 & 40 & 45 & 45 \\
\hline Health, Medicine and Life & & & & & & \\
\hline Sciences & 3,000 & 3,950 & 4,200 & 37 & 40 & 36 \\
\hline Arts and Social Sciences & 1,800 & 3,000 & 3,900 & 40 & 40 & 40 \\
\hline Psychology and Neuroscience & 1,893 & 2,900 & 3,500 & 37 & 38 & 38 \\
\hline Law & 2,277 & 3,600 & 4,800 & 40 & 40 & 40 \\
\hline Maastricht University & 2,600 & 3,800 & 4,500 & 40 & 40 & 40 \\
\hline
\end{tabular}

\section{A look at employability in the broad sense} As the UM has employability of its students high on the agenda, this factsheet continues by putting emphasis

12 This observation mostly applies to alumni from Health and Life Sciences as the median monthly income among Medicine alumni sharply increases between the cohorts 1.5 and ten years after graduation, from $€ 3400$ to $€ 6746$.

13 Whereas $10 \%$ of the alumni from Psychology and Neuroscience both works for an employer and are selfemployed, this percentage is only $6.7 \%$ for the UM as a whole (five years after graduation). See also ROA-F-2018/4E. 


\section{Factsheet}

ROA-F-2018/9

on specific employability measures. ${ }^{14,15}$ Employability is all about getting and remaining employed, especially in an ever changing labour market. In that sense, employability does not only deal with having a job, but also with being able to keep this job and, in case of losing a job, with the probability of being able to find a comparable job.

Table 4 shows graduates' perceived risk of losing their current job as well as the perceived probability of finding a comparable job if needed. In general, the vast majority of the graduates feel quite secure about their current job. Only $9 \%$ and $8 \%$ of the alumni five and ten years after graduation expect to lose their current job fin the upcoming five years. Additionally alumni from both cohorts feel confident in finding a comparable job if they would lose their current job, namely $76 \%$ and $71 \%$ for the 2011-2012 and 2006-2007 cohorts respectively.

Across faculties, we observe differences in the perceived probability of remaining employed. Five years after graduation, alumni from the School of Business and Economics are most confident in maintaining their job and finding a comparable job if they would lose their job. Only $3 \%$ expects to lose their current job in the next five years. If needed, $84 \%$ of the School of Business and Economics alumni expects to get a comparable job. Alumni from the Faculty of Arts and Social Sciences also perceive a relatively low risk of losing their job five years after graduation (5\%), whereas they perceive an average probability of finding a comparable job in case they would need to find one. Alumni from the Faculty of Arts and Social Sciences who graduated about ten years ago, perceive more difficulties in finding a comparable job. On the contrary, alumni from Psychology and Neuroscience who graduated ten years ago expect to lose their job less often and expect to find a comparable job more often than similar alumni who graduated five years ago. Among alumni from Law those who graduated about ten years ago perceive a much lower

14 See Community at the Core: Strategic Programme 20172021 for Maastricht University's strategy on graduate employability.

15 In 2017, the questionnaire among UM alumni five and ten years after graduation has been revised in order to be able to comment more on (the broad concept of) employability of former UM students. The NAE (questionnaire 1.5 years after graduation) does not have this focus. risk of losing their current job than Law alumni five years after graduation.

TABLE 4.

Percentage of alumni who estimate to lose their jobs and percentage of alumni who estimate to be able to find a comparable job after losing their job

\begin{tabular}{|l|c|c|c|c|} 
& \multicolumn{2}{|c|}{ \% risk losing current job } & \multicolumn{2}{c|}{ \% find comparable job } \\
& 2011 & 2006 & 2011 & 2006 \\
\hline & - & - & - & - \\
\hline Humanities and Sciences & 2012 & 2007 & 2012 & 2007 \\
\hline $\begin{array}{l}\text { Business and Economics } \\
\text { Health, Medicine and Life }\end{array}$ & 3 & $\mathrm{x}$ & 70 & $\mathrm{x}$ \\
\hline Sciences & 13 & 10 & 73 & 69 \\
\hline Arts and Social Sciences & & & & \\
\hline Psychology and Neuroscience & 19 & 11 & 75 & 62 \\
\hline Law & 11 & 4 & 67 & 79 \\
\hline Maastricht University & 9 & 8 & 73 & 71 \\
\hline X & & & 76 & 71 \\
\hline
\end{tabular}

$\mathrm{x}=$ too few cases

Employability comprises more than getting and remaining employed. A broader definition of employability also includes aspects such as job satisfaction, (fulfilling) job content and lifelong learning. ${ }^{16}$

Table 5 shows for UM alumni (from the different faculties) both the degree of job satisfaction and the extent to which their jobs have a broader societal impact. Generally, most UM graduates appear to be satisfied with their current job: $81 \%$ and $78 \%$ of the UM alumni are (very) satisfied with their current job five and ten years after graduation. Moreover, approximately two thirds of the Maastricht University alumni tend to have jobs that have a broader societal impact. Differences across faculties, and to a lesser extent over the two cohorts, do exist. Five years after graduation, alumni from Health, Medicine and Life Sciences are most satisfied with their job: $91 \%$ is (very) satisfied with their current job. Ten years after graduation, this holds for $75 \%$. Alumni from Psychology and Neuroscience and from Law are most satisfied with their jobs ten years after graduation. Five years after graduation, respectively $74 \%$ and $71 \%$ is satisfied.

16 See ROA-R-2017/2 


\section{Maastricht University Graduate Surveys 2018}

Alumni from Health Medicine and Life Sciences (86\%) and Humanities and Sciences (80\%) report the highest societal impact five years after graduation. ${ }^{17}$ Among School of Business and Economics alumni, these percentages are relatively low (around $47 \%$ ).

TABLE 5.

Percentage of UM graduates who are satisfied with their current job and percentage of UM graduates that realise societal impact within their current job

\begin{tabular}{|l|c|c|c|c|}
\hline & \multicolumn{3}{|c|}{ \% satisfied with job } & \multicolumn{2}{c|}{$\begin{array}{c}\text { \% broader societal } \\
\text { impact }\end{array}$} \\
& 2011 & 2006 & 2011 & 2006 \\
\hline Humanities and Sciences & - & - & - & - \\
\hline Business and Economics & 2012 & 2007 & 2012 & 2007 \\
\hline Health, Medicine and Life & 80 & $\mathrm{x}$ & 80 & $\mathrm{x}$ \\
\hline Sciences & 91 & 80 & 47 & 52 \\
\hline Arts and Social Sciences & 75 & 86 & 81 \\
\hline Psychology and Neuroscience & 74 & 84 & 67 & 56 \\
\hline Law & 71 & 88 & 65 & 71 \\
\hline Maastricht University & 81 & 78 & 65 & 70 \\
\hline X too few cases & & & & \\
\hline
\end{tabular}

Table 6 shows the degree of lifelong learning among UM alumni. We distinguish between training participation in the last two years and informal learning on-thejob. ${ }^{18}$ On average, five and ten years after graduation $36 \%$ and $33 \%$ of UM alumni had followed a job-related training in the past two years. This is relatively low compared to the Dutch average of $63 \%$ among high educated workers. ${ }^{19}$ The differences between cohorts and faculties are distinct. Focusing on the graduation cohort of $2011-2012,60 \%$ of alumni from the faculty of Humanities and Sciences participated in formal training, whereas only $24 \%$ of alumni from the faculty of Arts and Social Sciences did so. Also among the UM alumni who graduated in 2006-2007, the training participation is lowest for alumni from Arts and Social Sciences (15\%). Alumni from Law and the School of Business

17 We do not have enough observations to draw conclusions for alumni from Humanities and Sciences who graduated about ten years ago.

18 Informal learning is defined as the percentage of working time spent on tasks from which one can learn. See also ROA-F-2017/4E for comparisons with the Dutch working population.

$19 \mathrm{ROA}-\mathrm{F}-2017 / 4 \mathrm{E}$ and Economics have the highest training participation among this cohort.

Informal training is measured as the percentage of working time alumni usually spend on tasks from which one can learn. On average, a little less than half of the working time is spent on tasks from which UM alumni can learn. There are not so many differences across faculties.

TABLE 6.

Percentage UM alumni spend on formal - and informal training in their job

\begin{tabular}{|l|c|c|c|c|}
\hline & \multicolumn{3}{|c|}{$\%$ training } & \% informal learning \\
& 2011 & 2006 & 2011 & 2006 \\
\hline & - & - & - & - \\
\hline Humanities and Sciences & 2012 & 2007 & 2012 & 2007 \\
\hline Business and Economics & 60 & $\mathrm{x}$ & 48 & $\mathrm{x}$ \\
\hline Health, Medicine and Life & 36 & 42 & 43 & 46 \\
\hline Sciences & 31 & 30 & 47 & 40 \\
\hline Arts and Social Sciences & 24 & 15 & 39 & 42 \\
\hline Psychology and Neuroscience & 32 & 33 & 50 & 46 \\
\hline Law & 47 & 42 & 48 & 38 \\
\hline Maastricht University & 36 & 33 & 46 & 42 \\
\hline X too few cases & & & & \\
\hline
\end{tabular}

\section{Satisfaction with study at Maastricht University}

UM alumni are also asked to look back to their study at Maastricht University and indicate whether they would choose the same study again. We report on this in Table 7. Among the youngest cohort, $75 \%$ of all UM alumni would choose the same study at the UM again. Across all faculties and cohorts, at least two thirds of the graduates would choose the same study at the UM again.

TABLE 7.

Percentage of alumni who would choose the same study again

\begin{tabular}{|l|c|c|c|}
\hline & $2015-2016$ & $2011-2012$ & $2006-2007$ \\
\hline Humanities and Sciences & 95 & 75 & $\mathrm{x}$ \\
\hline Business and Economics & 81 & 79 & 78 \\
\hline Health, Medicine and Life Sciences & 73 & 81 & 70 \\
\hline Arts and Social Sciences & 65 & 75 & 73 \\
\hline Psychology and Neuroscience & 67 & 66 & 75 \\
\hline Law & 79 & 85 & 84 \\
\hline Maastricht University & 75 & 78 & 75 \\
\hline
\end{tabular}

$x=$ too few cases 


\section{Factsheet ROA-F-2018/9}

\section{Appendix A}

TABLE 8.

Unemployment ${ }^{1}$

\begin{tabular}{|c|c|c|c|c|c|c|c|c|c|}
\hline & $\begin{array}{c}2010 \\
T+1 \\
2008-2009\end{array}$ & $\begin{array}{c}2011 \\
T+1 \\
2009-2010\end{array}$ & $\begin{array}{c}2012 \\
T+1 \\
2010-2011\end{array}$ & $\begin{array}{c}2013 \\
T+1 \\
2011-2012\end{array}$ & $\begin{array}{c}2014 \\
\mathrm{~T}+1 \\
2012-2013\end{array}$ & & $\begin{array}{c}2015 \\
\mathrm{~T}+1 \\
2013-2014\end{array}$ & $\begin{array}{c}2016 \\
\mathrm{~T}+1 \\
2014-2015\end{array}$ & $\begin{array}{c}2017 \\
\mathrm{~T}+1 \\
2015-2016\end{array}$ \\
\hline Business and Economics & - & 4.9 & 6 & 6.3 & 5.7 & & 3.6 & 0.0 & 0 \\
\hline Health and Life Sciences & - & 4.4 & 8.3 & 16.4 & 10.3 & & 9.2 & 8.0 & 7.1 \\
\hline Medicine & - & 0 & 1.7 & 2.5 & 3.3 & & 2.7 & 0.0 & 3.9 \\
\hline Arts and Social Sciences & - & 23.9 & 25.5 & 33.3 & 13.7 & & 5.9 & 5.6 & 22.9 \\
\hline \multicolumn{10}{|l|}{ Psychology and } \\
\hline Neuroscience & - & 11.4 & 16.7 & 25.6 & 7.6 & & 10.3 & 14.1 & 7.3 \\
\hline Law & - & 8.8 & 7.1 & 14.3 & 16.2 & & 10.3 & 14.6 & 7.7 \\
\hline \multirow[t]{2}{*}{ Maastricht University } & - & 7.5 & 10 & 13.8 & 9.2 & & 6.9 & 6.6 & 6.9 \\
\hline & $\begin{array}{c}2010 \\
T+5 \\
2003-2004\end{array}$ & $\begin{array}{c}2011 \\
T+5 \\
2004-2005\end{array}$ & $\begin{array}{c}2012 \\
T+5 \\
2005-2006\end{array}$ & $\begin{array}{c}2013 \\
T+5 \\
2006-2007\end{array}$ & $\begin{array}{c}2014 \\
T+5 \\
2007-2008\end{array}$ & $\begin{array}{c}2015 \text { spring } \\
\text { T+5 } \\
2008-2009\end{array}$ & $\begin{array}{c}2015 \text { fall } \\
\text { T+5 } \\
2009-2010\end{array}$ & $\begin{array}{c}2016 \\
T+5 \\
2010-2011\end{array}$ & $\begin{array}{c}2017 \\
\mathrm{~T}+5 \\
2011-2012\end{array}$ \\
\hline Business and Economics & 2.2 & 5.4 & 1.9 & 0 & 0 & 0.9 & 1.5 & 1.3 & 1.2 \\
\hline Health and Life Sciences & 1.7 & 2.7 & 2.1 & 3.1 & 3.5 & 4.3 & 5.3 & 3.3 & 1.7 \\
\hline Medicine & 0 & 1.5 & 0 & 0 & 1.3 & 0.0 & 4.9 & 0 & 0 \\
\hline Arts and Social Sciences & $x$ & 3.8 & 10.1 & 5.7 & 4.8 & 4.4 & 6.7 & 1.5 & 5.7 \\
\hline \multicolumn{10}{|l|}{ Psychology and } \\
\hline Law & 4.3 & 5 & 0 & 6.8 & 3.8 & 2.6 & 1.8 & 0 & 1.6 \\
\hline \multirow[t]{2}{*}{ Maastricht University } & 2.5 & 4.4 & 2.7 & 3.2 & 2.6 & 2.6 & 3.4 & 1.5 & 2.2 \\
\hline & $\begin{array}{c}2010 \\
T+10 \\
1998-1999\end{array}$ & $\begin{array}{c}2011 \\
T+10 \\
1999-2000\end{array}$ & $\begin{array}{c}2012 \\
T+10 \\
2000-2001\end{array}$ & $\begin{array}{c}2013 \\
T+10 \\
2001-2002\end{array}$ & $\begin{array}{c}2014 \\
T+10 \\
2002-2003\end{array}$ & $\begin{array}{c}2015 \text { spring } \\
T+10 \\
2003-2004\end{array}$ & $\begin{array}{c}2015 \text { fall } \\
T+10 \\
2004-2005\end{array}$ & $\begin{array}{c}2016 \\
T+10 \\
2005-2006\end{array}$ & $\begin{array}{c}2017 \\
T+10 \\
2006-2007\end{array}$ \\
\hline Business and Economics & 3 & 2.8 & 0.9 & 0.9 & 0.7 & 1.0 & 0 & 1.6 & 1.1 \\
\hline Health and Life Sciences & 0.6 & 2 & 1.2 & 3.1 & 3.7 & 0.6 & 2.6 & 1.6 & 1.4 \\
\hline Medicine & 0 & 2.6 & 1.8 & 0 & 2 & 3.6 & 1.5 & 1.2 & 0 \\
\hline Arts and Social Sciences & $x$ & $x$ & $x$ & $x$ & $x$ & 4.3 & 11.5 & 4.4 & 4.6 \\
\hline \multicolumn{10}{|l|}{ Psychology and } \\
\hline Law & 1.5 & 0 & 6.1 & 1.6 & 0 & 1.4 & 0 & 0 & 6.9 \\
\hline Maastricht University & 1.7 & 2 & 2 & 2 & 2.1 & 1.5 & 3 & 1.7 & 2.6 \\
\hline
\end{tabular}

1 too little information on the Faculty of Humanities and Sciences.

$\mathrm{x}=$ too few cases 


\section{Imprint}

(c) Research Centre for Education and the Labour Market (ROA).

Nothing in this publication may be duplicated in any way

without prior written permission from ROA's director.

Research Centre for Education and the Labour Market

Maastricht University

School of Business and Economics

secretary-roa-sbe@maastrichtuniversity.n

www.roa.nl

\section{Layout}

ROA Secretariat, Maastricht

April 2018 